\title{
EFFECT OF SOME SOIL AMENDMENTS ON GROWTH, YIELD AND QUALITY OF TOMATO PLANTS (LYCOPERSICON ESCULENTUM MILL.) CULTIVATED UNDER SALINITY CONDITIONS \\ Kamal, A. M.* and M. M. El-Shazly ${ }^{\star *}$ \\ * Veget. Res. Dept., Hort. Res. Inst., Agric. Res. Center, Giza, Egypt \\ ${ }^{*}$ Soil Fertility and Plant Nutrition Dep., Soil, Water and Environment Res. Inst., Agric. Res. Center, Giza, Egypt
}

\begin{abstract}
Two field experiments were conducted at Kalabsho region, El-Dakahlia Governorate, Egypt, during 2010 and 2011 seasons to evaluate the effect of some soil amendments, i.e., agricultural gypsum, rice straw mulching and cyanobacteria inoculation as well as their combinations on growth, chemical composition, yield and fruit quality of tomato plants (Fiona F1 hybrid) cultivated under salinity conditions in northern of the Nile Delta.

The obtained results confirm that the combined addition of agricultural gypsum (applied according to the gypsum requirements at 4.34 ton fed $^{-1}$ ) + rice straw mulching $\left(12\right.$ ton $\left.\mathrm{fed}^{-1}\right)+$ inoculation of tomato seedlings before transplanting with cyanobacteria (2 liter $\mathrm{fed}^{-1}$ ) had the highest significant vegetative growth characteristics (number of branches, relative growth rate and net assimilation rate) and chemical composition $\left(\mathrm{N}, \mathrm{P}, \mathrm{K}, \mathrm{Ca}\right.$ and $\mathrm{K}^{+} / \mathrm{Na}^{+}$ratio as well as total chlorophyll contents) in tomato plant foliage. This treatment also had the significant increases in fruit setting percentage and marketable yield as well as the highest significant values of fruit quality characteristics (vitamin C, TSS and lycopene content) with the lowest nitrite accumulation comparing with the untreated plants (control), which had the minimum quality aspects of tomato fruits in both seasons. Such treatment is found to be economically and more agronomically feasible. It showed the highest net return and returned the highest benefit-cost ratio (1.87) in comparison with the other treatments.

In conclusion, this investigation demonstrates that the combined application of agricultural gypsum (4.34 ton fed $\left.^{-1}\right)+$ rice straw mulching $\left(12\right.$ ton fed $\left.^{-1}\right)+$ inoculation of tomato seedlings before transplanting with cyanobacteria could be recommended to improve the vegetative growth characteristics, chemical composition, marketable yield and fruit quality. It proved to be the economical for tomato production under salinity conditions to ensure the optimum and the satisfactory utilization of the new reclaimed land.
\end{abstract}

\section{INTRODUCTION}

Tomato (Lycopersicon esculentum Mill.) is one of the most widely cultivated vegetables in Egypt. Beside the great nutritive value as a good source of minerals, vitamins and natural antioxidants, tomato has an economically attractive as a cash vegetable crop. Kalabsho region is a new reclaimed land located in Northern of the Nile Delta, Egypt. It is distinguished by the moderate weather, especially during the summer season, that unique weather is appropriate for the late summer cultivation of tomato plants, which has always been the most important for farmers because of high prices. 
According to the classification salt content of soils (FAO, 2006) Kalabsho region soil is classified as strongly salty with EC of 6.55 and $6.82 \mathrm{dSm}^{-1}$ in both seasons, respectively, meanwhile, the available irrigation source can be classified as medium saline water (FAO, 1985), it is a Nile water highly affected by saline agricultural drainage water with EC of 3.01 and $3.26 \mathrm{dSm}^{-1}$, during the two growing seasons, respectively.

Unfortunately, tomato plants have been classified as moderately salt sensitive crop with threshold value of $2.5 \mathrm{dSm}^{-1}$ and a dramatically yield decrease about $9.9 \%$ per dSm${ }^{-1}$ (Mass, 1990). Salinity conditions of soil and irrigation water through their high osmotic pressures affect growth by restricting the uptake of water and essential nutritional ions by tomato plants roots (Tester and Devenport, 2003) that seriously limits the potential of tomato production, resulting in lowering the profitability of this important vegetable crop in such region. One of the known soil amendments commonly used in reclamation salinity-affected soils is the application of agricultural gypsum that led to reducing salinity hazards (Abbas et al., 2004 and Saeed and Ahmad, 2009). Recently, a great attention has been given to other new technologies of combating salinity depending on the use of friendly organic materials, such as organic mulching with rice straw which is one of the most plentiful crop residues in Egypt. Many studies showed that straw mulching is a promising management option for farmers to control soil salinity as it decreases soil water evaporation as well as regulates soil and water salt movement (Yang et al., 2006). Organic mulching directly provides organic $C$ inputs to soil and has been used to effectively suppress weeds and reduce soil erosion (Jordan, 2004). Moreover, it has been used to obtain good vegetable growth and yield of tomato plants under salinity conditions (Rahman et al., 2006; Saeed and Ahmad, 2009). Abul-Hashem (2001) showed that cyanobacterial biofertilizer could be used to reclaim soil problems such as saline and low fertility soils. Cyanobacteria is a phylum of bacteria that obtain their energy through photosynthesis. The majorities of cyanobacteria are capable of fixing atmospheric nitrogen and are effectively used as biofertilizers and soil conditioner (Vaishampayan et al., 2001). Cyanobacteria inoculation was reported to increase plant growth and yield of many plants such as tomato (Rizvi and Sharma, 1994); rice (Song et al., 2005) and common bean (Hegazi et al., 2010).

This work is an attempt to improve the performance of tomato plants grown under salinity conditions by adding agricultural gypsum, rice straw mulching and cyanobacteria.

\section{MATERIALS AND METHODS}

Two field experiments were carried out at a private farm at Kalabsho region, El-Dakahlia Governorate, Egypt, during 2010 and 2011 seasons to investigate the effect of some soil amendments, i.e., agricultural gypsum, rice straw mulching and cyanobacteria inoculation treatment on growth, chemical composition, yield and fruit quality of tomato plants cultivated under soil and water irrigation salinity conditions. Some 
physical and chemical properties of the experimental soil and irrigation water are present in Tables 1 and 2. The analysis was carried out according to the methods described by Page et al. (1982) and Klute (1986).

Table 1: Some physical and chemical properties of the experimental soil during the growing seasons of 2010 and 2011

\begin{tabular}{|c|c|c|c|c|c|}
\hline Properties & $\begin{array}{c}1^{\text {st }} \\
\text { Season }\end{array}$ & $\begin{array}{c}2^{\text {nd }} \\
\text { season }\end{array}$ & Properties & $\begin{array}{c}1^{\text {st }} \\
\text { season }\end{array}$ & $\begin{array}{c}2^{\text {nd }} \\
\text { Season }\end{array}$ \\
\hline Sand & 81.1 & 79.4 & \multicolumn{3}{|c|}{ Available macro-nutrients (ppm) } \\
\hline Silt & 14.3 & 16.7 & $\mathrm{~N}$ & 3.11 & 3.74 \\
\hline Clay & 4.6 & 4.9 & $\mathrm{P}$ & 3.61 & 3.24 \\
\hline Texture class & Loamy sand & Loamy sand & $\mathrm{K}$ & 25.2 & 17.4 \\
\hline O.M. (\%) & 0.42 & 0.53 & \multicolumn{3}{|c|}{ Soluble cations (meq $100 \mathrm{~L}^{-1}$ ) } \\
\hline $\mathrm{pH}$ & 8.20 & 8.24 & $\mathrm{Na}^{+}$ & 41.11 & 46.88 \\
\hline $\begin{array}{l}\text { CEC (meq/100 g } \\
\text { soil) }\end{array}$ & 8.64 & 8.42 & $\mathrm{Ca}^{++}$ & 11.25 & 12.17 \\
\hline ESP (\%) & 31.07 & 33.44 & $\mathrm{Mg}^{++}$ & 12.33 & 8.74 \\
\hline$E C\left(\mathrm{dSm}^{-1}\right)$ & 6.55 & 6.82 & $\mathrm{~K}^{+}$ & 0.81 & 0.39 \\
\hline $\mathrm{CaCO}_{3}(\%)$ & 0.43 & 0.48 & \multicolumn{3}{|c|}{ Soluble anions (meq $100 \mathrm{~L}^{-1}$ ) } \\
\hline Bulk density $\left(\mathrm{kg} \mathrm{m}^{-3}\right)$ & 1.62 & 1.57 & $\mathrm{SO}_{4}=$ & 14.96 & 19.22 \\
\hline Field capacity (\%) & 14.2 & 13.4 & $\mathrm{HCO}^{-}$ & 3.41 & 4.51 \\
\hline $\mathrm{GR}^{*}\left(\right.$ ton fed $\left.{ }^{-1}\right)$ & 4.16 & 4.51 & $\mathrm{Cl}^{-}$ & 44.11 & 42.77 \\
\hline
\end{tabular}

${ }^{*}$ Gypsum requirement $=4.34$ ton fed $^{-1}$

Table 2: Chemical characteristics of the used irrigation water during the growing seasons of 2010 and 2011

\begin{tabular}{|l|c|c|c|c|c|c|c|c|c|}
\hline \multirow{2}{*}{ Season } & \multirow{2}{*}{$\mathrm{pH}$} & $\mathrm{EC}$ & \multicolumn{4}{|c|}{ Soluble cations (meq $\mathrm{L}-1)$} & \multicolumn{3}{c|}{ Soluble anions (meq $\mathrm{L}-1)$} \\
\cline { 5 - 11 } & & $\left(\mathrm{dSm}^{-1}\right)$ & $\mathrm{K}^{+}$ & $\mathrm{Na}^{+}$ & $\mathrm{Mg}^{2+}$ & $\mathrm{Ca}^{2+}$ & $\mathrm{SO}^{4=}$ & $\mathrm{Cl}^{-}$ & $\mathrm{HCO}^{3-}$ \\
\hline $1^{\text {st }}$ season & 7.63 & 3.01 & 0.67 & 18.2 & 6.84 & 4.41 & 4.78 & 12.12 & 5.41 \\
\hline $2^{\text {nd }}$ season & 7.91 & 3.26 & 0.21 & 21.3 & 5.23 & 5.84 & 2.89 & 10.47 & 7.87 \\
\hline
\end{tabular}

On July, $1^{\text {st }}$ week in both seasons of the study, 45 day old tomato seedlings (Fiona F1 hybrid, product of Sluis \& Groot, Erakhuizen, Holland) were transplanted in open field using furrow irrigation at $50 \mathrm{~cm}$ apart on one side of the ridge.

\section{Layout of experiment and treatments:}

The experimental unit consisted of eight ridges each of $1 \mathrm{~m}$ wide and $3.5 \mathrm{~m}$ long with plot area of $28 \mathrm{~m}^{2}$. A complete randomized block design with three replicates was adopted to include eight treatments as follows: Control (T1); Agricultural gypsum (T2); Rice straw mulching (T3); Cyanobacteria inoculation (T4); Agricultural gypsum + Rice straw mulching (T5); Agricultural gypsum + Cyanobacteria inoculation (T6); Rice straw mulching + cyanobacteria inoculation (T7) and finally, Agricultural gypsum + Rice straw mulching + Cyanobacteria inoculation (T8).

The experiment included three main soil additions; agricultural gypsum (70\% purity), which was applied at 4.16 and 4.51 ton fed ${ }^{-1}$ during the two seasons, respectively, according to the gypsum requirements calculation based on the soil analyses (Table 1) as stated by James and Topper (1993). Agricultural gypsum was added two weeks before 
transplanting by flipping thoroughly in the $30^{\text {th }} \mathrm{cm}$ soil layer followed by heavy irrigation. Local rice straw as the organic mulching treatment, was applied 20 days after transplanting to the rows at 12 ton $\mathrm{fed}^{-1}$ (about $10 \mathrm{~cm}$ thickness). Two salt tolerant strains of cyanobacteria (Anabaena variabilis and Nostoc calcicola) obtained from Soils, Water and Environment Research Institute, Agricultural Research Center, Egypt, were used to inoculate tomato seedlings once before transplanting. Two liter fed ${ }^{-1}$ of active cyanobacteria cell suspension were dissolved in 4 liter of tap water and mixed with Arabic gum as an adhesive substance. The other agricultural treatments for growing tomato plants were followed according to the instruction laid down by Horticulture Research Institute, Agricultural Research Center, Egypt.

\section{Data recorded:}

\section{Growth measurements:}

Five plants from each plot at 75 days after transplanting were randomly taken for determination of number of branches per plant. At 45 and 75 days after transplanting, foliage dry weight and leaf area per plant were estimated and were used to calculate relative growth rate (Hunt, 1990) and net assimilation rate (Gardner et al., 1985) as follows:

$\operatorname{RGR}\left(\mathrm{mg} / \mathrm{gm}\right.$. day $\left.^{-1}\right)=\left[\left(\ln \mathrm{W}_{2}-\ln \mathrm{W}_{1}\right) /\left(\mathrm{T}_{2}-\mathrm{T}_{1}\right)\right] \times 1000$

NAR $\left(\mathrm{mg} / \mathrm{cm}^{2}\right.$ day $\left.^{-1}\right)=\left[\left(\mathrm{W}_{2}-\mathrm{W}_{1}\right) /\left(\mathrm{T}_{2}-\mathrm{T}_{1}\right)\right] \times\left[\left(\mathrm{In} \mathrm{LA} 2-\ln \mathrm{LA}_{1}\right) /\left(\mathrm{LA}_{2}-\mathrm{LA}_{1}\right)\right]$ $\mathrm{X} 1000$

Where; RGR: relative growth rate; NAR: net assimilation rate; In: natural logarithm; $W_{1}$ : dry weight of plant shoots at time one (in gram); $W_{2}$ : dry weight of plant shoots at time two (in gram); $T_{1}$ : time one (in day); $T_{2}$ : time two (in day); LA 1 : leaf area/ plant (Koller, 1972) at time one $\left(\mathrm{cm}^{2}\right)$; LA 2 : leaf area/ plant at time two.

\section{Chemical analysis:}

Representative samples of tomato plant foliage from each plot at 75 days after transplanting were used to determine $\mathrm{N}, \mathrm{P}, \mathrm{K}, \mathrm{Ca}$ and $\mathrm{Na}$ contents (\%) in dry weight. Total nitrogen was determined according to the methods described by Bremner and Mulvaney (1982). Phosphorus was estimated colormetrically according to Olsen and Sommers (1982). Potassium and sodium were assayed spectrophotometrically according to Johanson and Ulrichs (1959). Calcium was determined by titration with versinate (Page et al., 1982). The $\mathrm{K}^{+} / \mathrm{Na}^{+}$ratio was determined by dividing the $\mathrm{K}^{+}(\%)$ on $\mathrm{Na}^{+}$ (\%). Representative samples from the fourth upper leaves were taken to determinate total chlorophyll content (SPAD units) using a portable leaf chlorophyll meter (Minolta Model SPAD 501) according to Murquard and Timpton (1987).

\section{Fruit setting, yield and quality measurements:}

Four uniform plants from each plot were randomly chosen and labeled then fruit setting percentage was recorded (all over the season). All harvested fruits from each plot at full maturity stage along the season were used to determine the unmarketable tomato yield (calculated from all disordered tomato fruits) and total marketable yield (calculated from all harvested marketable fruits) as tons per feddan. A representative sample of 10 tomato fruits from each experimental plot at the marketable ripe stage was taken from the third harvest for determination of fruits quality characteristics, 
i.e., vitamin C, total soluble solids (TSS) and nitrite contents according to the methods described by AOAC (1990). Lycopene content in fruits was determinate as described by Fish et al. (2002).

\section{Statistical analysis:}

The obtained data were subjected to statistical analysis by the technique of analysis of variance (ANOVA) according to Snedecor and Cochran (1982). The means of treatments were compared using the least significant difference (LSD) at probability level $(P) \leq 0.05$.

Economic feasibility of cultivation tomato plants, i.e., gross return, treatment cost, total variable cost, net return and benefit-cost ratio were calculated based on market prices as average of the two seasons. The benefit-cost ratio was determined according to Boardman et al. (2001) by dividing the gross return $\left(\mathrm{LE} \mathrm{fed}^{-1}\right)$ on total variable cost $\left(\mathrm{LE} \mathrm{fed}^{-1}\right)$.

\section{RESULTS AND DISCUSSION}

\section{Vegetative growth characteristics:}

Some growth characteristics of tomato plants cultivated under salinity conditions are presented in Table 3 . The obtained data clearly showed that addition of agricultural gypsum + rice straw mulching + cyanobacteria inoculation treatment (T8) had the significant effect on all studied vegetative growth parameters, i.e., number of branches, relative growth rate and net assimilation rate followed by the addition of agricultural gypsum + rice straw mulching treatment (T5) in comparison to the other treatments. It is also clear that the lowest significant values were recorded by the control treatment in both seasons of the study. The results are in agreement with that reported by Rahman et al. (2006) they found that plant height of tomato plants increased by mulching with rice straw under saline soil. Moreover, Saeed and Ahmad (2009) reported that plant height, fresh and dry vegetative biomass of tomato plants reached the highest significant values with the addition of organic mulching and agricultural gypsum under saline conditions. Furthermore, under Kalabsho region conditions, EL-Said (2009) stated that application of 2.5 ton of agricultural gypsum as soil amendment had a significant effect on number of leaves, plant height, roots, shoots and total dry weight of tomato plants. Meanwhile, Rizvi and Sharma (1994) demonstrated that soil inculation with cyanobacteria stimulated fresh and dry of tomato plants. Such results also are in agreement with Al-Khiat (2006) who reported that cyanobacteria induced a high significant increase in leaf area, dry weight of shoots and roots of tomato seedlings. 
Table 3: Vegetative growth characteristics of tomato plants as affected by agricultural gypsum, rice straw mulching and cyanobacteria applications during 2010 and 2011 seasons

\begin{tabular}{|c|c|c|c|c|c|c|}
\hline \multirow{2}{*}{ Treatment } & \multicolumn{2}{|c|}{ No. branches/ plant } & \multicolumn{2}{c|}{$\begin{array}{c}\text { Relative growth rate } \\
\left(\mathbf{m g} / \mathbf{g m}_{\left.\text {day }^{-1}\right)}\right.\end{array}$} & $\begin{array}{c}\text { Net assimilation rate } \\
\left(\mathbf{m g} / \mathbf{c m}^{2} \text { day }^{\mathbf{1}}\right)\end{array}$ \\
\cline { 2 - 7 } & $\begin{array}{c}\mathbf{1}^{\text {st }} \\
\text { Season }\end{array}$ & $\begin{array}{c}\mathbf{2}^{\text {nd }} \\
\text { season }\end{array}$ & $\begin{array}{c}\mathbf{1}^{\text {st }} \\
\text { season }\end{array}$ & $\begin{array}{c}\mathbf{2}^{\text {nd }} \\
\text { season }\end{array}$ & $\begin{array}{c}\mathbf{1}^{\text {st }} \\
\text { season }\end{array}$ & $\begin{array}{c}\mathbf{2}^{\text {nd }} \\
\text { season }\end{array}$ \\
\hline T1 & 7.94 & 6.71 & 23.15 & 20.14 & 0.215 & 0.227 \\
\hline T2 & 8.91 & 7.88 & 30.47 & 27.99 & 0.255 & 0.269 \\
\hline T3 & 8.36 & 7.21 & 29.43 & 27.06 & 0.239 & 0.257 \\
\hline T4 & 7.98 & 6.82 & 28.10 & 25.67 & 0.228 & 0.244 \\
\hline T5 & 9.17 & 8.49 & 31.39 & 29.19 & 0.262 & 0.276 \\
\hline T6 & 8.94 & 8.17 & 30.82 & 28.44 & 0.257 & 0.271 \\
\hline T7 & 8.22 & 7.71 & 28.92 & 27.16 & 0.237 & 0.250 \\
\hline T8 & 9.42 & 8.78 & 32.27 & 29.94 & 0.269 & 0.284 \\
\hline LSD at 5\% & 0.211 & 0.229 & 0.709 & 0.724 & 0.006 & 0.007 \\
\hline T1: Con
\end{tabular}

T1: Control; T2: Agricultural gypsum; T3: Rice straw mulching; T4: Cyanobacteria; T5 Agricultural gypsum + Rice straw mulching; T6: Agricultural gypsum + Cyanobacteria; T7: Rice straw mulching + Cyanobacteria; T8: Agricultural gypsum + Rice straw mulching + Cyanobacteria.

The pronounced promotional effect of the agricultural gypsum on vegetative growth of tomato plants under salinity conditions may be due to the several benefits of agricultural gypsum as it contains $23 \%$ calcium and $18 \%$ sulfur, since calcium plays a great role to ameliorate the salinity hazards by reducing the water potential in plant leaves through preserve the structural and functional integrity of cell membranes, stabilize cell wall structure, regulate ion transport and selectivity as well as control ion-exchange behavior, also, calcium is needed to flocculate clays in alkaline soils (Marschner, 1995). Moreover, salt-affected soils are characterized by the occurrence of sodium $\left(\mathrm{Na}^{+}\right)$at levels that result in poor physical properties and fertility problems, thereby threatening plant growth and productivity. Agricultural gypsum provides these soils with soluble source of calcium $\left(\mathrm{Ca}^{2+}\right)$ which replace excess $\mathrm{Na}^{+}$on the cation exchange sites; the replaced $\mathrm{Na}^{+}$is leached from the root zone through leaching irrigation (Oster, 1982). Furthermore, agricultural gypsum decreases soil pH (Andrade et al., 2002) and electrical conductivity (Soni et al., 1997) by the oxidation of sulphur to $\mathrm{H}_{2} \mathrm{SO}_{4}$, which is particularly beneficial in alkaline soils to reduce $\mathrm{pH}$, supply $\mathrm{SO}_{4}$ to plants, make $\mathrm{P}$ and micronutrients more available (Burns, 1967) and easily absorbed by plant roots. Additionally, mulching with straw under saline conditions was reported to decrease salt content in about $0-40 \mathrm{~cm}$ deep soil and lower the water potential in leaves consequently reduces the salinity hazard (Rahman et al., 2006 and Yang et al., 2006). Moreover, soil inoculation with cyanobacteria was reported to produce many growthpromoting hormones such as auxin, gibberellins, vitamins and amino acids (Rodriguez et al., 2006). Cyanobacteria influences positively the biological activity and chemical properties of soil, where the soil $\mathrm{pH}$ and electrical conductivity (EC) were reported to decrease by inoculation with cyanobacteria (Hegazi et al., 2010). Such flocculation led to remarkable 
enhancement in vegetative growth of tomato plants under salinity conditions. On the other hand, the negative effect on the untreated (control) tomato plants (T1) can be explained based on the deleterious effect of salinity on the water status, ions uptake, protein and nucleic acid synthesis as well as on photosynthesis, enzyme activities and hormonal balance, as accordingly, restricting the cellular processes including cell division and expansion (Rodriguez et al., 2006) that eventually reduces plant growth. In this respect, Dehan and Tal (1977) reported that when tomato plants grown in high salt media, $\mathrm{Na}^{+}$ions are transported and accumulated in leaf tissues and consequently become inhibitory to photosynthetic activities. Such behaviors resulted in the disturbance of all metabolic process and led to flimsy vegetative growth. However, all these obstacles may be avoided by the application of the proposed combination (agricultural gypsum + rice straw mulching + cyanobacteria) that reported in this study.

\section{Chemical composition of plant foliage:}

The chemical profile of tomato plant foliage is presented in Tables 4 and 5. There were significant differences among the different treatments on the concentration of $\mathrm{N}, \mathrm{P}, \mathrm{K}, \mathrm{Ca}, \mathrm{Na}$ and $\mathrm{K}^{+} / \mathrm{Na}^{+}$ratio as well as total chlorophyll contents of tomato plant foliage.

Table 4: Chemical composition of tomato plant foliage as affected by agricultural gypsum, rice straw mulching and cyanobacteria applications during 2010 and 2011 seasons

\begin{tabular}{|c|c|c|c|c|c|c|}
\hline \multirow{2}{*}{ Treatment } & \multicolumn{2}{|c|}{$\mathbf{N}(\%)$} & \multicolumn{2}{c|}{$\mathbf{P}$ (\%) } & \multicolumn{2}{c|}{$\mathbf{K}(\%)$} \\
\cline { 2 - 7 } & $\begin{array}{c}\mathbf{1}^{\text {st }} \\
\text { Season }\end{array}$ & $\begin{array}{c}\mathbf{2}^{\text {nd }} \\
\text { season }\end{array}$ & $\begin{array}{c}\mathbf{1}^{\text {st }} \\
\text { season }\end{array}$ & $\begin{array}{c}\mathbf{2}^{\text {nd }} \\
\text { season }\end{array}$ & $\begin{array}{c}\mathbf{1}^{\text {st }} \\
\text { season }\end{array}$ & $\begin{array}{c}\mathbf{2}^{\text {nd }} \\
\text { season }\end{array}$ \\
\hline T1 & 1.93 & 2.07 & 0.225 & 0.210 & 2.61 & 2.74 \\
\hline T2 & 2.42 & 2.64 & 0.296 & 0.270 & 3.32 & 3.41 \\
\hline T3 & 2.38 & 2.58 & 0.267 & 0.256 & 2.98 & 3.30 \\
\hline T4 & 2.24 & 2.46 & 0.232 & 0.218 & 2.72 & 2.85 \\
\hline T5 & 2.48 & 2.68 & 0.305 & 0.270 & 3.35 & 3.50 \\
\hline T6 & 2.44 & 2.61 & 0.297 & 0.263 & 3.24 & 3.43 \\
\hline T7 & 2.28 & 2.47 & 0.248 & 0.231 & 2.81 & 2.91 \\
\hline T8 & 2.65 & 2.80 & 0.307 & 0.288 & 3.49 & 3.76 \\
\hline LSD at 5\% & 0.121 & 0.101 & 0.013 & 0.011 & 0.145 & 0.133 \\
\hline
\end{tabular}

T1: Control; T2: Agricultural gypsum; T3: Rice straw mulching; T4: Cyanobacteria; T5: Agricultural gypsum + Rice straw mulching; T6: Agricultural gypsum + Cyanobacteria; T7: Rice straw mulching + Cyanobacteria; T8: Agricultural gypsum + Rice straw mulching + Cyanobacteria. 
Table 5: Chemical composition of tomato plant foliage as affected by agricultural gypsum, rice straw mulching and cyanobacteria applications during 2010 and 2011 seasons

\begin{tabular}{|c|c|c|c|c|c|c|c|c|}
\hline \multirow{2}{*}{ Treatment } & \multicolumn{2}{|c|}{ Ca (\%) } & \multicolumn{2}{c|}{ Na (\%) } & \multicolumn{2}{c|}{$\mathbf{K}^{+} / \mathbf{N a}^{+}$ratio } & \multicolumn{2}{c|}{$\begin{array}{c}\text { Total chlorophyll } \\
\text { (SPAD unit) }\end{array}$} \\
\cline { 2 - 9 } & $\begin{array}{c}\mathbf{1}^{\text {st }} \\
\text { season }\end{array}$ & $\begin{array}{c}\mathbf{2}^{\text {nd }} \\
\text { season }\end{array}$ & $\begin{array}{c}\mathbf{1}^{\text {st }} \\
\text { season }\end{array}$ & $\begin{array}{c}\mathbf{2}^{\text {nd }} \\
\text { season }\end{array}$ & $\begin{array}{c}\mathbf{1}^{\text {st }} \\
\text { season }\end{array}$ & $\begin{array}{c}\mathbf{2}^{\text {nd }} \\
\text { season }\end{array}$ & $\begin{array}{c}\mathbf{1}^{\text {st }} \\
\text { season }\end{array}$ & $\begin{array}{c}\mathbf{2}^{\text {nd }} \\
\text { season }\end{array}$ \\
\hline T1 & 1.82 & 1.77 & 1.28 & 1.15 & 2.04 & 2.38 & 44.18 & 48.31 \\
\hline T2 & 2.18 & 2.06 & 1.16 & 1.07 & 2.86 & 3.19 & 50.96 & 56.78 \\
\hline T3 & 2.06 & 1.88 & 1.22 & 1.11 & 2.44 & 2.97 & 50.34 & 55.49 \\
\hline T4 & 1.85 & 1.81 & 1.28 & 1.16 & 2.13 & 2.46 & 43.83 & 45.90 \\
\hline T5 & 2.27 & 2.14 & 1.12 & 1.04 & 2.99 & 3.37 & 53.95 & 58.02 \\
\hline T6 & 2.28 & 2.10 & 1.15 & 1.06 & 2.82 & 3.24 & 53.32 & 56.27 \\
\hline T7 & 1.97 & 1.93 & 1.22 & 1.14 & 2.30 & 2.55 & 53.11 & 54.30 \\
\hline T8 & 2.37 & 2.23 & 1.09 & 1.02 & 3.20 & 3.69 & 55.38 & 61.06 \\
\hline LSD at 5\% & 0.035 & 0.045 & 0.021 & 0.019 & 0.051 & 0.037 & 1.35 & 1.81 \\
\hline
\end{tabular}

T1: Control; T2: Agricultural gypsum; T3: Rice straw mulching; T4: Cyanobacteria; T5: Agricultural gypsum + Rice straw mulching; T6: Agricultural gypsum + Cyanobacteria; T7: Rice straw mulching + Cyanobacteria; T8: Agricultural gypsum + Rice straw mulching + Cyanobacteria.

It is clear that the increment of element content, i.e., $\mathrm{N}, \mathrm{P}, \mathrm{K}, \mathrm{Ca}, \mathrm{Na}$ and $\mathrm{K}^{+} / \mathrm{Na}^{+}$ratio as well as total chlorophyll reached the highest significant values with the combined addition of agricultural gypsum + organic mulching + inculation with cyanobacteria treatment (T8) followed by the addition of agricultural gypsum + rice straw mulching treatment (T5) in comparison with the other treatments and control in both seasons. The exception was that of $\mathrm{Na}$ content during both seasons, which reach the highest significant value with the untreated plants (T1), while the minimum value was obtained by the integrated addition of agricultural gypsum + rice straw mulching + inculation with cyanobacteria treatment (T8) followed by the addition of agricultural gypsum + rice straw mulching treatment (T5). The results had the same trend during both seasons. Such results are in agreement with the previously confirmed results by several authors, e.g., Saeed and Ahmad (2009) they observed that application of organic mulch and agricultural gypsum under soil salinity conditions increased total chlorophyll, total protein, total soluble carbohydrate and $\mathrm{K}^{+}$uptake as well as $\mathrm{K}^{+} / \mathrm{Na}^{+}$ratio, whereas, the $\mathrm{Na}^{+}$content in dry weight of tomato leaves was significantly reduced. Moreover, EL-Said (2009) illustrated that the addition of 2.5 ton $^{-1} d^{-1}$ of agricultural gypsum under Kalabsho region conditions resulted in the highest significant $\mathrm{N}$ and $\mathrm{P}$ concentration and N, P and K uptake of tomato plants. Al-Khiat (2006) mentioned that addition of cyanobacteria as a soil conditioner increased $\mathrm{K}$, chlorophyll $\mathrm{a}$ and $\mathrm{b}$ as well as decreased $\mathrm{Na}$ content in tomato shoots.

The balanced and improved chemical composition of tomato foliage is expected, especially when applying agricultural gypsum + rice straw mulching + cyanobacteria inculation treatment (T8), in which the combined action of such treatment markedly alleviated the salinity hazards of the soil, it was observed that such treatment tended to be more effective than the other treatments and control in improving and recovering mineral status of tomato plants, particularly the minerals of tomato foliar $\mathrm{N}, \mathrm{P}, \mathrm{K}$ and $\mathrm{Ca}$ with the lowest $\mathrm{Na}^{+}$content. Such gains could be attributed based on the known role 
that addition of agricultural gypsum to the saline soil was the most effective to increase soluble $\mathrm{Ca}$ ions, available $\mathrm{N}, \mathrm{P}$ and $\mathrm{K}$, soil total porosity, field capacity, wilting point and available water content, also decreasing soluble $\mathrm{Na}^{+}$, exchangeable sodium percent (ESP) and soil bulk density (Abbas et al., 2004). Moreover, it was reported that high $\mathrm{K}^{+} / \mathrm{Na}^{+}$ratio is important for plant salt tolerance (Gao et al, 2007). Additionally, the surface organic mulching has shown to reduce evaporation and decrease salinity hazards (Yang et al., 2006). Another possible reason for such improvement in tomato foliage chemical composition is that the combined application of organic mulching and agricultural gypsum under salinity stress increased the osmotic potential, carbohydrate, protein and the inorganic contents of tomato leaves, also showed a significant increase in $\mathrm{K}^{+} / \mathrm{Na}^{+}$ratio (Saeed and Ahmad, 2009). Moreover, the positive effect of cyanobacteria on chemical composition of tomato plant foliage under salinity condition may be due to the ability of cyanobacteria to remove $\mathrm{Na}^{+}$(Fernandes et al., 1993) by the production of exopolysaccharides, which had a decisive role in binding sodium ions from saline medium, thereby alleviating salt stress (Arora et al., 2010). Moreover, cyanobacteria produced many of growth promoting hormones, i.e., auxins, cytokinins and gibberellins (Hussain et al., 2010) the latter has been reported to reduce the bad effect of $\mathrm{NaCl}$ (Rodriguez et al., 2006) and hence, alleviation salinity hazards of the soil.

\section{Fruit setting, unmarketable and marketable yield:}

The following data presented in Table 6 are concerned with the effect of agricultural gypsum, rice straw mulching and cyanobacteria inoculation treatment on fruit setting, unmarketable and marketable yield of tomato plants cultivated under salinity conditions. The obtained data clearly show that the combined application of agricultural gypsum + rice straw mulching + cyanobacteria inoculation treatment (T8) show the highest significant values of fruit setting percentage and marketable yield of tomato followed by the addition of agricultural gypsum + rice straw mulching treatment (T5). Meanwhile, the lowest significant values in this respect were obtained with the control treatment (T1) which show the highest significant unmarketable tomato yield fed $\mathrm{d}^{-1}$. On the contrary the lowest unmarketable tomato yield was obtained by the combined application of agricultural gypsum + rice straw mulching + cyanobacteria inoculation treatment (T8). The results had the same trend during the two seasons. Such results are in line with Saeed and Ahmad (2009) they reported that number and weight of tomato fruits were maximized with organic mulching + agricultural gypsum treatment under saline conditions. Moreover, EL-Said (2009) indicated that addition of 2.5 ton $\mathrm{fed}^{-1}$ of agricultural gypsum under Kalabsho region conditions enhanced average fruit weight, number of fruits and fruit yield of tomato plant as well as total yield $\mathrm{fed}^{-1}$. Furthermore, cyanobacteria inoculation was reported to increase yield of tomato (Rizvi and Sharma, 1994) and common bean (Hegazi et al., 2010). 
Table 6: Fruit setting and yield characteristics of tomato plants as affected agricultural gypsum, rice straw mulching and cyanobacteria applications during 2010 and 2011 seasons

\begin{tabular}{|c|c|c|c|c|c|c|}
\hline \multirow{2}{*}{ Treatment } & \multicolumn{2}{|c|}{ Fruit setting (\%) } & \multicolumn{2}{|c|}{$\begin{array}{c}\text { Unmarketable yield } \\
\text { (ton fed }^{-1} \text { ) }\end{array}$} & \multicolumn{2}{|c|}{$\begin{array}{l}\text { Marketable yield } \\
\left(\text { ton fed } \text { fed }^{-1}\right)\end{array}$} \\
\hline & $\begin{array}{c}1^{\text {st }} \\
\text { season }\end{array}$ & $\begin{array}{c}2^{\text {nd }} \\
\text { season }\end{array}$ & $\begin{array}{c}1^{\text {st }} \\
\text { season }\end{array}$ & $\begin{array}{c}2^{\text {nd }} \\
\text { season }\end{array}$ & $\begin{array}{c}1^{\text {st }} \\
\text { season }\end{array}$ & $\begin{array}{c}2^{\text {nd }} \\
\text { season }\end{array}$ \\
\hline T1 & 61.47 & 64.77 & 4.06 & 3.66 & 10.85 & 12.74 \\
\hline T2 & 67.99 & 72.64 & 3.21 & 3.01 & 13.39 & 14.13 \\
\hline T3 & 64.66 & 66.14 & 3.41 & 3.10 & 12.53 & 14.60 \\
\hline T4 & 60.42 & 63.41 & 4.15 & 3.59 & 11.02 & 12.54 \\
\hline T5 & 71.88 & 74.27 & 2.84 & 2.65 & 14.03 & 16.12 \\
\hline T6 & 71.08 & 72.91 & 2.94 & 2.88 & 13.51 & 15.62 \\
\hline T7 & 65.72 & 68.12 & 3.74 & 2.97 & 12.61 & 15.12 \\
\hline T8 & 74.01 & 77.15 & 2.53 & 2.34 & 15.32 & 17.24 \\
\hline LSD at $5 \%$ & 2.02 & 1.87 & 0.110 & 0.092 & 0.422 & 0.473 \\
\hline
\end{tabular}

T1: Control; T2: Agricultural gypsum; T3: Rice straw mulching; T4: Cyanobacteria; T5: Agricultural gypsum + Rice straw mulching; T6: Agricultural gypsum + Cyanobacteria; T7: Rice straw mulching + Cyanobacteria; T8: Agricultural gypsum + Rice straw mulching + Cyanobacteria.

The mentioned cited interpretation due the application of agricultural gypsum, rice straw mulch and cyanobacteria may be due to their enhancing impact on vegetative growth behaviors of tomato plants (Table 3), that associated with the recovering of the mineral status of tomato plants (Table 4 and 5), particularly $\mathrm{Ca}$ contents that certainly reflected on the bioassimilation process of the whole metabolic machinery, those known to be reflected in similar beneficial way on fruit yield responses of tomato plants. Meanwhile, the adverse impact on fruit setting percentage with the untreated plants (T1) is mainly due to the negative effect of soil and water salinity as it showed the highest $\mathrm{N}^{+}$content and the lowest $\mathrm{K}^{+} / \mathrm{Na}^{+}$ratio in tomato plant foliage (Table 5 ) that closely related with the decreasing in fruit sitting under such conditions. However, fruit setting percentage and yield of tomato responded negatively to the increment in salinity level (Tantawy et al., 2009). Moreover, surface organic mulching with rice straw is an effective application to isolate tomato fruits from direct contact with soil this isolation reflected on the significant decrease in unmarketable tomato yield.

Fruit quality characteristics:

Regarding to the effect of agricultural gypsum, rice straw mulching and inoculation with cyanobacteria on the quality aspects of tomato fruits, it is obvious from data in Table 7 that vitamin C, TSS and lycopene contents were significantly affected positively by the combined application of agricultural gypsum + rice straw mulching + cyanobacteria inoculation treatment (T8). Meanwhile, nitrite content reached the lowest value with such treatment in comparison with the untreated plants (control), which showed the lowest vitamin C, TSS and lycopene as well as the highest nitrite content in tomato fruits in both seasons. Similar results were reported by EL-Said (2009) on tomato who showed that application of 2.5 ton fed $^{-1}$ of agricultural gypsum as a soil amendment under Kalabsho region conditions had a significant improvements on vitamin $\mathrm{C}$ and total carbohydrates content of tomato fruits. 
Table 7: Quality characteristics of tomato fruits as affected by agricultural gypsum, rice straw mulching and cyanobacteria applications during 2010 and 2011 seasons

\begin{tabular}{|c|c|c|c|c|c|c|c|c|}
\hline \multirow[t]{2}{*}{ Treatment } & \multicolumn{2}{|c|}{$\begin{array}{c}\text { Vitamin C } \\
(\mathrm{mg} / 100 \mathrm{~g} F \mathrm{~F})\end{array}$} & \multicolumn{2}{|c|}{ TSS (\%) } & \multicolumn{2}{|c|}{$\begin{array}{l}\text { Nitrite content } \\
{\text { ( } \mathrm{mg} \mathrm{kg}^{-1} \text { fresh }}_{\text {fruit) }}\end{array}$} & \multicolumn{2}{|c|}{$\begin{array}{l}\text { Lycopene } \\
\text { (mg kg-1 fresh }_{\text {fruit) }}\end{array}$} \\
\hline & $\begin{array}{c}1^{\text {st }} \\
\text { Season }\end{array}$ & $\begin{array}{c}2^{\text {nd }} \\
\text { season }\end{array}$ & $\begin{array}{c}1^{\text {st }} \\
\text { season }\end{array}$ & $\begin{array}{c}2^{\text {nd }} \\
\text { season }\end{array}$ & $\begin{array}{c}1^{\text {st }} \\
\text { season }\end{array}$ & $\begin{array}{c}2^{\text {nd }} \\
\text { season }\end{array}$ & $\begin{array}{c}1^{\text {st }} \\
\text { Season }\end{array}$ & $\begin{array}{c}2^{\text {nd }} \\
\text { season }\end{array}$ \\
\hline T1 & 19.52 & 22.97 & 7.10 & 6.32 & 0.358 & 0.496 & 55.41 & 52.74 \\
\hline T2 & 20.57 & 23.75 & 6.92 & 6.21 & 0.319 & 0.442 & 62.66 & 57.88 \\
\hline T3 & 20.12 & 22.69 & 6.78 & 6.23 & 0.325 & 0.462 & 58.73 & 54.19 \\
\hline T4 & 19.63 & 21.87 & 6.99 & 6.28 & 0.331 & 0.481 & 54.47 & 52.34 \\
\hline T5 & 21.70 & 24.40 & 7.16 & 6.31 & 0.315 & 0.419 & 64.21 & 60.06 \\
\hline T6 & 21.01 & & 7.05 & 6.28 & 0.321 & 0.438 & 61.96 & 57.44 \\
\hline T7 & 20.03 & 22.98 & 7.08 & 6.27 & 0.327 & 0.451 & 58.81 & 56.26 \\
\hline T8 & 23.46 & 25.97 & 7.31 & 6.44 & 0.290 & 0.398 & 67.33 & 62.55 \\
\hline LSD a & 1.34 & 1.41 & 0.14 & 0.11 & 0.025 & 0.030 & 2.67 & 2.41 \\
\hline
\end{tabular}

T1: Control; T2: Agricultural gypsum; T3: Rice straw mulching; T4: Cyanobacteria; T5: Agricultural gypsum + Rice straw mulching; T6: Agricultural gypsum + Cyanobacteria; T7: Rice straw mulching + Cyanobacteria; T8: Agricultural gypsum + Rice straw mulching + Cyanobacteria.

The stimulatory effect of the combined addition of agricultural gypsum + rice straw mulching + cyanobacteria inoculation treatment (T8) on quality characteristics of tomato fruits may be related to their ameliorative effect on potassium content as well as $\mathrm{K}^{+} / \mathrm{Na}^{+}$ratio in plant foliage (Table 5), as potassium is closely related with fruit quality characters, it plays an important role in water status of plant, promoting the translocation of newly synthesized photosynthesis and mobilization of stored materials as well as promoting the synthesis of sugars and polysaccharides (Mengel and Kirkby, 1982). Herein, the increment of nitrite content in tomato fruits with the control treatment may be due to the metabolic toxicity of $\mathrm{Na}^{+}$and its great ability to compete with $\mathrm{K}^{+}$for binding sites essential for cellular function, thus, high levels of $\mathrm{Na}^{+}$(Table 5) can disrupt various enzymatic processes in the cytoplasm including protein synthesis that requires high concentration of $\mathrm{K}^{+}$ (Tester and Davenport, 2003). Furthermore, polysaccharides, which produced by cyanobacteria increases soil water holding capacity through their jelly structure (Rogers and Burns, 1994) such behavior are known to be closely associated with the water status in plant tissues, particularly under salinity conditions that related positively with fruit quality (Mitchell and Shennan, 1991).

\section{Economic feasibility:}

The economic feasibility of cultivation tomato plants in the presence of agricultural gypsum, rice straw mulching and cyanobacteria inoculation treatment under salinity conditions are presented in Table 8 . The results showed that the highest net return $\left(11328 \mathrm{LE} \mathrm{fed}^{-1}\right)$ was obtained under the combined application of agricultural gypsum + rice straw mulching + cyanobacteria inoculation treatment (T8); such treatment returns the highest benefit-cost ratio (1.87) in comparison with the other treatments. Thus, this treatment proved to be economical for tomato production under the conditions of this study. 
Table 8: Economic performance of tomato plants as affected agricultural gypsum, rice straw mulching and cyanobacteria applications during 2010 and 2011 seasons

\begin{tabular}{|c|c|c|c|c|c|c|c|}
\hline Treatment & $\begin{array}{c}\text { Marketable } \\
\text { yield } \\
\left(\text { ton } \text { fed }^{-1}\right)^{(1)}\end{array}$ & $\begin{array}{l}\text { Gross } \\
\text { return } \\
\left(\text { LE fed }^{-1}\right)^{(2)}\end{array}$ & $\begin{array}{l}\text { Treatment } \\
\text { cost } \\
(L E \text { fed- } \\
1)^{(3)}\end{array}$ & $\begin{array}{c}\text { Total variable } \\
\text { cost } \\
\left(\text { LE fed }^{-1}\right)^{(4)}\end{array}$ & $\begin{array}{l}\text { Net return } \\
\left(\text { LE fed }^{-1}\right)^{(5)}\end{array}$ & $\begin{array}{c}\text { Benefit- } \\
\text { cost } \\
\text { ratio( }^{(6)}\end{array}$ & Order \\
\hline $\mathrm{T} 1$ & 11.80 & 17693 & 0 & 11370 & 6323 & 1.56 & 7 \\
\hline T2 & 13.76 & 20640 & 892 & 12262 & 8378 & 1.68 & 6 \\
\hline T3 & 13.57 & 20348 & 660 & 12030 & 8318 & 1.69 & 5 \\
\hline $\mathrm{T} 4$ & 11.78 & 17670 & 170 & 11540 & 6130 & 1.53 & 8 \\
\hline T5 & 15.08 & 22613 & 1552 & 12922 & 9691 & 1.75 & 3 \\
\hline T6 & 14.57 & 21848 & 1062 & 12432 & 9416 & 1.76 & 2 \\
\hline T7 & 13.87 & 20798 & 830 & 12200 & 8598 & 1.70 & 4 \\
\hline T8 & 16.28 & 24420 & 1722 & 13092 & 11328 & 1.87 & 1 \\
\hline
\end{tabular}

(1) Tomato marketable yield as average of two seasons. (2) Gross return as marketable yield (ton fed ${ }^{-1}$ ) $\times 1500$ LE ton $^{-1}$. (3) Treatment cost was calculated according to the following prices; agricultural gypsum $=170$ LE ton ${ }^{-1}$, Rice straw $=45$ LE ton ${ }^{-1}$,

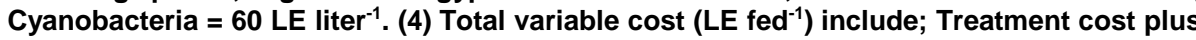
land leasehold, transplants, NPK fertilizers, microelements, pesticides, labors, and other agricultural practices, which equal nearly 11370 LE fed $^{-1} ;(5)=(2)-(4) .(6)=(2) /(4)$.

T1: Control; T2: Agricultural gypsum; T3: Rice straw mulching; T4: Cyanobacteria; T5: Agricultural gypsum + Rice straw mulching; T6: Agricultural gypsum + Cyanobacteria; T7: Rice straw mulching + Cyanobacteria; T8: Agricultural gypsum + Rice straw mulching + Cyanobacteria.

In conclusion, this investigation demonstrates that the combined application of agricultural gypsum (5.94 ton fed ${ }^{-1}$ ), rice straw mulching (12 ton $\mathrm{fed}^{-1}$ ) and inoculation of tomato seedlings before transplanting with cyanobacteria could be recommended to improve the vegetative growth characteristics, chemical composition, marketable yield and tomato fruit quality. It proved to be the economical for tomato production under salinity conditions to ensure the optimum and the satisfactory utilization of the new reclaimed land.

\section{REFERENCES}

Abbas, H. H.; E. H. A. Noufal; S. M. Abd El-Aziz and H. S. Saeid (2004). Workshop on agricultural development in the Arab nation, Obstacles and Solutions, Jan. 20-22, Assiut, Egypt, pp. 319-335.

Abul-Hashem, M. D. (2001). Problems and prospects of cyanobacterial biofertilizer for rice cultivation. Aust. J. plant physiol., 28:881-888.

Al-Khiat, S. H. A. (2006). Effect of cyanobacteria as a soil conditioner and biofertilizer on growth and some biochemical characteristics of tomato (Lycopersicon esculentum L.) seedlings. M. Sc. Thesis, King Saud Univ. Fac. of Scie. Botany and Microbio. Dep., pp. 190.

Andrade, A. T.; L. A. Fernandes and V. Faquin (2002). Organic residue, Limestone, gypsum and phosphorus adsorption by lowland soils. Scientia Agricola, 59(2): 349-355.

AOAC (1990). Official Methods of Analysis of the Association of Official Edition, Washington, D. C. 
Arora, M.; A. Kaushik; N. Rani and C. P. Kaushik (2010). Effect of cyanobacterial exopolysaccharides on salt stress alleviation and seed germination. J. Environmental Biology, 31(5): 701-704.

Boardman, A. E.; D. H. Greenberg; A. R. Vining and D. L. Weimer (2001). Cost-benefit analysis. Concepts and practice. $2^{\text {nd }}$ ed. Prentice Hall, Upper Saddle River.

Bremner, J. M. and C. S. Mulvaney (1982). Total nitrogen. In: Page, A. L.; R. H. Miller and D. R. Keeney (Eds) Methods of Soil Analysis. Part 2, Amer. Soc. Agron. Madison, W. I. USA, pp. 595- 624.

Burns, G. R. (1967). Oxidation of sulfur in soils. Tech. Bull. 13. The Sulphur Institute, Washington, D.C.

Dehan, K. and M. Tal (1977). Salt tolerance in the wild relatives of the cultivated tomato: Responses of Solanum pennellii to high salinity. Irrig. Sci., 1:71-76.

EL-Said, M. EL-S. (2009). A comparative study for impact of low phosphorus fertilization in different combinations with sulphur, gypsum and phosphorein on tomato growth, mineral status and productivity. J. Agric. Sci. Mansoura Univ., 34(5): 4829 -4840.

FAO (1985). Water Quality for Agriculture. Irrigation and Drainage. Technical Paper, No 29. Rome, Italy.

FAO (2006). Guidelines for soil description. $4^{\text {th }}$ ed., FAO publ., Rome, pp. 40.

Fernandes, T. A.; V. Iyer and S. K. Apte (1993). Differential responses of nitrogen fixing cyanobacteria to salinity and osmotic stress. Appl. Environ. Microbiol., 59: 899-904.

Fish, W. W.; P. Perkins-Veaziea and J. K. Collins (2002). Quantitative assay for lycopene that utilizes reduced volumes of organic solvents. J. Food Comp. Anal., 15(3): 309-317.

Gao, J. P., D. Y. Chao and H. X. Lin (2007). Understanding abiotic stress tolerance mechanisms: recent studies on stress response in rice. J. Integr. Plant Biol., 49: 742-750.

Gardner, F.; R. Pearce and R. L. Mitchell (1985). Physiology of crop plants. lowa State University Press, Ames, USA, pp. 66.

Hegazi, A. Z.; S. S. M. Mostafa and H. M. I. Ahmed (2010). Influence of different cyanobacterial application methods on growth and seed production of common bean under various levels of mineral nitrogen fertilization. Nature and Science, 8 (11): 183- 194.

Hunt, R. (1990). Basic growth analysis: Plant growth analysis for beginners. Unwin Hyman, London. pp.112.

Hussain A.; M. Krischke; T. Roitsch and S. Hasnain (2010). Rapid determination of cytokinins and auxin in cyanobacteria. Curr Microbiol., 61: 361-369.

James, D. W. and K. F. Topper (1993). Utah Fertilizer Guide. Utah State Univ., USA, pp. 74.

Johanson, C. M. and A. Ulrichs (1959). Analytical methods for use in plant analysis, U.S. Dept. Agric. Inform. Bull., pp. 766.

Jordan, C. F. (2004). Organic farming and agroforestry: Alley cropping for mulch production for organic farms of southeastern United States. Agroforestry Systems, 61/62: 79-90. 
Klute, A. (1986). Method of Soil Analysis. Part I. $2^{\text {nd }}$ ed. Agron. Monogr. 9. ASA, Madison, WI.

Koller, H. R. (1972). Leaf area-leaf weight relationships in the Soybean canopy. Crop Sci., 12 (3/4): 180-183.

Marschner, H. (1995). Mineral nutrition of higher plants. Academic Press, London. pp.889.

Mass, E. V. (1990). Crop salt tolerance. In: Agricultural Salinity Assessment and Management. (Ed) KK Tanji. ASCE Manuals and Reports on Engineering Practice No. 71. ASCE, New York.

Mengel, K. and E. A. Kirkby (1982). Textbook of principles of plant nutrition. $3^{\text {rd }}$ ed. P: 655 . International Potash Institute, Bern, Switzerland.

Mitchell J. P. and C. Shennan (1991). Tomato fruit yields and quality under water deficit and salinity. J. Amer. Soc. Hort. Sci., 116(2): 215-221.

Murquard, R. D. and J. L. Timpton (1987). Relationship between extractable chlorophyll and an insitu method to estimate leaf green. Hort. Sci., 22(6): 1327.

Olsen, S. R. and L. E. Sommers (1982). Phosphorus. In: Page, A. L.; R. H. Miller and D. R. Keeney (eds). Methods of soil analysis. Part 2 Amer. Soc. Agron. Madison, W. I. USA, pp. 403-430.

Oster, J. D. (1982): Gypsum usage in irrigated agriculture: A review. Fertilizer Research. 3: 73-89.

Page, J. S.; R. H. Miller and D. R. Kenney (1982). Methods of Soil Analysis, Part 2, USA, SSSA. Modison, Wisconson, USA.

Rahman, M. J.; M. S. Uddin; S. A. Bagum; A. T. M. A. I. Mondol and M. M. Zaman (2006). Effect of mulches on the growth and yield of tomato in the coastal area of Bangladesh under rainfed condition. Int. J. Sustain. Crop. Prod., 1: 06-10.

Rizvi, Z. and V .K. Sharma (1994). Algae as biofertilizer for tomato plants. Recent Advances Phycology, pp. 221-223.

Rodriguez, A. A.; A. M. Stella; M. M. Storni; G. Zulpa and M. C. Zaccaro (2006). Effects of cyanobacterial extracellular products and gibberellic acid on salinity tolerance in Oryza sativa L., Saline Systems, pp. 2-7.

Rogers, S. L. and R. G. Burns (1994). Changes in aggregate stability, nutrient status, indigenous microbial populations and seedlings emergence following inoculation of soil with Nostoc muscorum. Biol. Fertil Soils, 18:209-215.

Saeed R. and R. Ahmad (2009). Vegetative growth and yield of tomato as affected by the application of organic mulching and gypsum under saline rhizosphere. Pak. J. Bot., 41(6): 3093-3105.

Snedecor, G. W. and W. G. Cochran. (1982). Statistical Methods. $7^{\text {th }}$ ed. $2^{\text {nd }}$ printing, lowa State. Univ. Press, Ame., USA, pp. 507.

Song T.; L. Martensson; T. Eriksson; W. Zheng and U. Rasmussen (2005): Biodiversity and seasonal variation of the cyanobacterial assemblage in a rice paddy field in Fujian, China. The Federation of European Materials Societies Microbio. Ecology, 54: 131-140.

Soni, M. L.; A. Swarup and M. Singh (1997). Behavior of native and applied manganese during reclamation of sodic soil. J. the Indian Soc. of Soil Sci., 45(2): 349-354. 
Tantawy, A. S.; A. M. R. Abd El-Mawgoud; M. A. El-Nemr and Y. G. Chamoun (2009). Alleviation of salinity effects on tomato plants by application of amino acids and growth regulators. European $\mathrm{J}$. Scientific Res., 30(3):484-494.

Tester, M. and R. Davenport (2003). $\mathrm{Na}^{+}$tolerant and $\mathrm{Na}^{+}$transport in higher plants. Annals of Botany, 91: 503-527.

Vaishampayan, A.; Sinha, R. P.; Hader, D. P.; Dey, T.; Gupta, A. K.; Bhan, U. and Rao, A. L. (2001). Cyanobacterial biofertilizers in rice agriculture. Botanical Review, 67(4):453-516.

Yang, Y.; L. Xiao-jing; L. Wei-qiang and L. Cun-zhen (2006). Effect of different mulch materials on winter wheat production in desalinized soil in Heilonggang region of north China. J. Zhejiang Univ. Sci., 7: 858867.

$$
\begin{aligned}
& \text { تأثير بعض محسنات التربة علي نمو ومحصول وجودة ثمار الطماطم المنزرعة } \\
& \text { تحت ظروف الملوحة }
\end{aligned}
$$

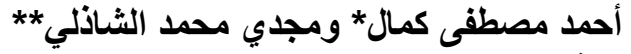

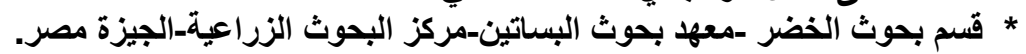

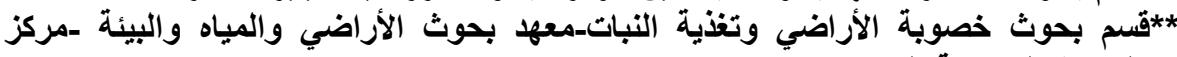

$$
\begin{aligned}
& \text { البحوث الزراعية_الجيزة مصر. الأري }
\end{aligned}
$$

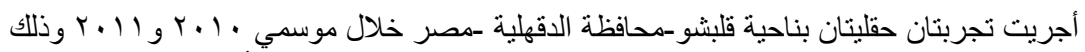

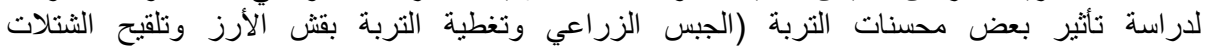

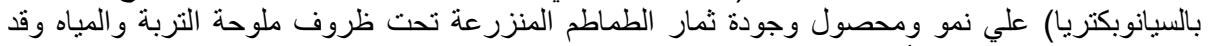

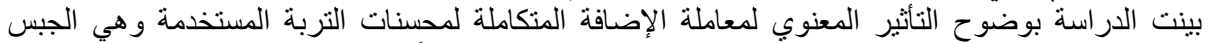

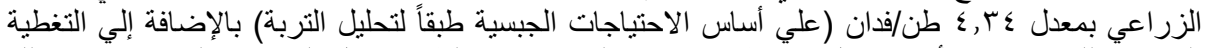

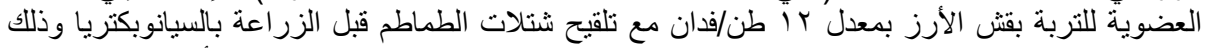

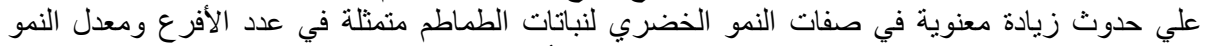

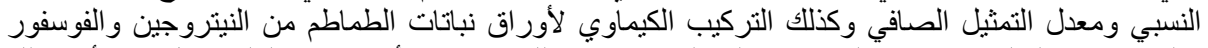

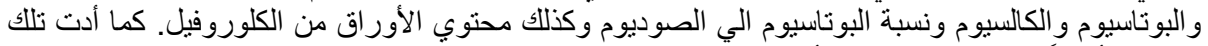

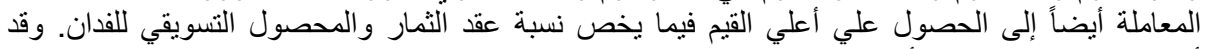

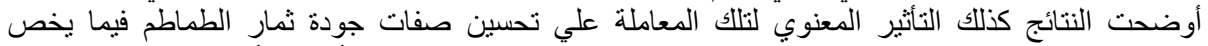

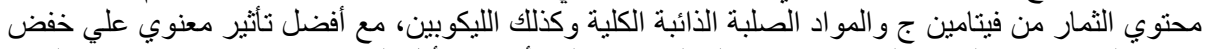

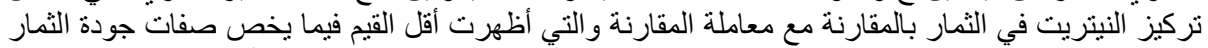

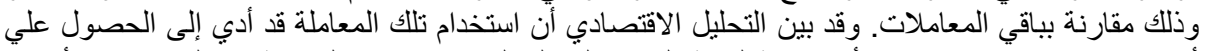

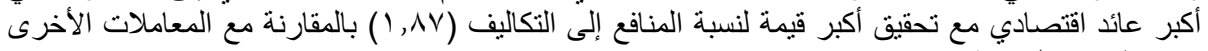
تحت ظروف التجربة.

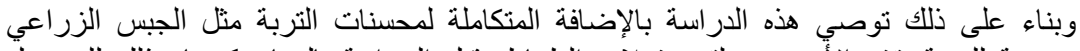

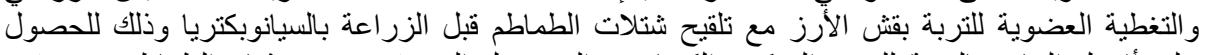

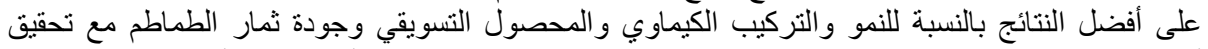
أفضل عائد اقتصادي تحت ظروف ملوحة التربة والمياه بما يكفل الاستغلال الأمثل لتلالك الأرض المستصلحة.

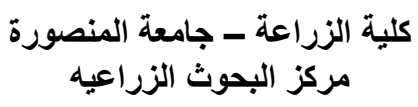

قام بتحكيم البحث

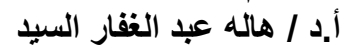

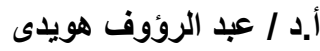

